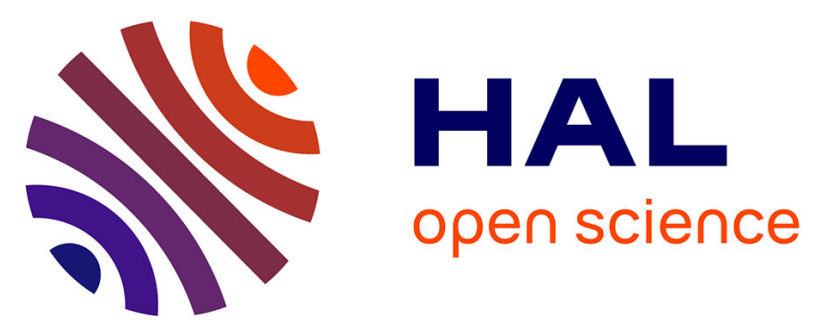

\title{
Hydraulic retention time affects bacterial community structure in an As-rich acid mine drainage (AMD) biotreatment process
}

Lidia Fernandez-Rojo, Corinne Casiot, Vincent Tardy, Elia Laroche, Pierre Le Pape, Guillaume Morin, Catherine Joulian, Fabienne Battaglia-Brunet, Charlotte Braungardt, Angelique Desoeuvre, et al.

\section{To cite this version:}

Lidia Fernandez-Rojo, Corinne Casiot, Vincent Tardy, Elia Laroche, Pierre Le Pape, et al.. Hydraulic retention time affects bacterial community structure in an As-rich acid mine drainage (AMD) biotreatment process. Applied Microbiology and Biotechnology, 2018, 102 (22), pp.9803-9813. 10.1007/s00253-018-9290-0 . hal-02129748

\section{HAL Id: hal-02129748 \\ https://hal.science/hal-02129748}

Submitted on 16 Feb 2021

HAL is a multi-disciplinary open access archive for the deposit and dissemination of scientific research documents, whether they are published or not. The documents may come from teaching and research institutions in France or abroad, or from public or private research centers.
L'archive ouverte pluridisciplinaire HAL, est destinée au dépôt et à la diffusion de documents scientifiques de niveau recherche, publiés ou non, émanant des établissements d'enseignement et de recherche français ou étrangers, des laboratoires publics ou privés. 


\section{Hydraulic retention time affects bacterial community structure in an As-rich acid mine drainage (AMD) biotreatment process}

Lidia Fernandez-Rojo ${ }^{1}$; Corinne Casiot ${ }^{1}$; Vincent Tardy $^{1}$; Elia Laroche ${ }^{1}$; Pierre Le Pape ${ }^{2}$; Guillaume Morin ${ }^{2}$; Catherine Joulian ${ }^{3}$; Fabienne Battaglia-Brunet ${ }^{3}$; Charlotte Braungardt ${ }^{4}$; Angélique Desoeuvre ${ }^{1}$; Sophie Delpoux ${ }^{1}$; Jolanda Boisson ${ }^{5}$; Marina Héry ${ }^{1}$.

${ }^{1}$ HydroSciences Montpellier, Univ. Montpellier-CNRS-IRD, Montpellier, France

${ }^{2}$ Institut de Minéralogie, de Physique des Matériaux et de Cosmochimie (IMPMC), UMR 7590 CNRS-UPMC-IRD-MNHN, 4, place Jussieu, 75252 Paris cedex 05, France

${ }^{3}$ French Geological Survey (BRGM), Geomicrobiology and environmental monitoring unit, 3, avenue Claude Guillemin, BP 36009, 45060 Orléans Cedex 2, France

4 School of Geography, Earth and Environmental Sciences (Faculty of Science \& Engineering), Plymouth University, United Kingdom

${ }^{5}$ IRH Ingénieur Conseil, Anteagroup, 197 avenue de Fronton, 31200, Toulouse, France 


\begin{abstract}
Arsenic removal consecutive to biological iron oxidation and precipitation is an effective process for treating As-rich acid mine drainage (AMD). We studied the effect of hydraulic retention time (HRT) - from 74 to $456 \mathrm{~min}$ - in a bench-scale bioreactor exploiting such process. The treatment efficiency was monitored during 19 days, and the final mineralogy and bacterial communities of the biogenic precipitates were characterized by X-ray absorption spectroscopy and high-throughput $16 \mathrm{~S}$ rRNA gene sequencing. The percentage of $\mathrm{Fe}(\mathrm{II})$ oxidation (10-47\%) and As removal (19-37\%) increased with increasing HRT. Arsenic was trapped in the biogenic precipitates as As(III)-bearing schwertmannite and amorphous ferric arsenate, with a decrease of As/Fe ratio with increasing HRT. The bacterial community in the biogenic precipitate was dominated by Fe-oxidizing bacteria whatever the HRT. The proportion of Gallionella and Ferrovum genera shifted from respectively 65 and $12 \%$ at low HRT, to 23 and $51 \%$ at high HRT, in relation with physico-chemical changes in the treated water. aioA genes and Thiomonas genus were detected at all HRT although As(III) oxidation was not evidenced. To our knowledge, this is the first evidence of the role of HRT as a driver of bacterial community structure in bioreactors exploiting microbial $\mathrm{Fe}(\mathrm{II})$ oxidation for AMD treatment.
\end{abstract}

Keywords: iron-oxidizing bacteria, biogenic precipitate, Gallionella, Ferrovum, arsenic removal, As(III) oxidation 


\section{Introduction}

Arsenic (As) is a toxic element present in many cases in acid mine drainage (AMD) ${ }^{1,2}$. One attractive, cost-effective way to treat As-rich AMD is to use the capacity of autochthonous microorganisms to immobilize this metalloid while oxidizing and precipitating iron ${ }^{3-5}$. This process is occurring naturally and has been described in many AMD streams worldwide ${ }^{6-8}$. It represents a promising strategy to remediate these effluents in a passive way, with minimum maintenance, which is a prerequisite in the management of these pollutions that last hundreds of years ${ }^{9}$.

In a recent study, we demonstrated that higher Fe(II) oxidation and As removal were obtained with increasing hydraulic retention time (HRT) in a bench-scale bioreactor treating As-rich AMD ${ }^{10}$. However, the effect of HRT on the microbial community structure and mineralogy of the biogenic precipitate was not investigated, although these features are major issues in the development of a bioremediation process.

By changing the physico-chemical parameters of the water, HRT may affect the bacterial community that drives the depollution and, in turn, treatment performance, robustness or sustainability, as observed in AMD treatments exploiting microbial sulfate reduction ${ }^{11,12}$. A number of studies have highlighted the role of $\mathrm{pH}^{13-15}$, conductivity ${ }^{16}$ or oxygen concentration ${ }^{17}$ in the structuration of microbial communities in AMD.

HRT is also expected to influence the As and Fe contents of the precipitate and, in turn, the mineralogy of As-bearing phases; the latter controls the concentration of aqueous As species in equilibrium with the solid and the potential reversibility of As trapping towards physicochemical changes or ageing ${ }^{18}$. 
In the present study, we investigated the effect of HRT on the composition of the bacterial community and the mineralogy of the biogenic precipitate in a bench-scale Fe-oxidation bioreactor treating As-rich AMD from the Carnoulès mine (southern France).

\section{Materials and methods}

\subsection{Bench-scale aerobic bioreactor}

The current bioreactor has been described in detail in our previous study ${ }^{10}$. Briefly, the bioreactor comprises four polyvinyl chloride (PVC) channels (C1-C4) of $1 \mathrm{~m}$ length, $0.06 \mathrm{~m}$ width and $0.06 \mathrm{~m}$ depth. A biodegradable mesh (BIO DURACOVER) was placed inside the channels to favor the adhesion of the biogenic precipitate. A peristaltic pump (Gilson, Minipuls 3) transferred AMD from a tank to the four channel inlets. Another pump was used to maintain the water height at $4 \mathrm{~mm}$. Each channel was fitted with a specific peristaltic pump tubing (Tygon ${ }^{\circledR}$ internal diameter (i.d.) $3.17,1.65,1.00$ and $0.76 \mathrm{~mm}$ ), thus setting a different flow rate value $\left(3.94,1.34,0.68\right.$ and $0.41 \mathrm{~mL} \mathrm{~min}^{-1}$, respectively) and hydraulic retention time $(\mathrm{HRT}=74,130,200$ and 456 min, respectively). The studied HRT values were chosen in a way they cover a range of iron oxidation efficiency from $\sim 10 \%$ to $\sim 90 \%$, according to our previous study ${ }^{10}$. Conditions of temperature and light were set up as previously described ${ }^{10}$.

\subsection{Experimental design}

Water was collected ( $200 \mathrm{~L})$ from the spring of the Reigous Creek on June $2^{\text {nd }}$ of 2015 in $20 \mathrm{~L}$ containers previously decontaminated with $65 \% \mathrm{HNO}_{3}$ and rinsed three times with in situ AMD. Once returned to the laboratory, the containers were purged with $\mathrm{N}_{2}$ until 
dissolved oxygen (DO) was lower than $\sim 1 \mathrm{mg} \mathrm{L}^{-1}$, in order to avoid Fe(II) oxidation. The containers were stored and successively used as feed water throughout the duration of the experiment. The experiment started on June $3^{\text {rd }}$ of 2015 , running in the four bioreactor channels (C) in parallel, each with a fixed HRT that was maintained throughout the experiment. Hence, the total volume of treated water at the end of the experiment varied from one channel to the other ( $\sim 105$ to $10 \mathrm{~L})$, depending on the flow rate.

During the initial setting-up stage of the experiment, a steady-state condition regarding Fe(II) oxidation within the channel was reached within 8 days. During that time, Fe precipitation promoted the formation of orange biogenic precipitates that covered the bottom of the channels ${ }^{10}$. Once the steady-state was reached, the efficiency of the treatment in terms of Fe oxidation, Fe precipitation and As removal, was evaluated for each channel, i.e. hydraulic retention time. The associated rates (in $\mathrm{mol} \mathrm{L}^{-1} \mathrm{~s}^{-1}$ ) were calculated using Equation 1,

$$
\text { Rate }=\frac{([X] \text { inlet }-[X] \text { outlet })}{H R T}
$$

Equation 1

where $[\mathrm{X}]$ was the concentration of dissolved Fe(II), total dissolved Fe, total dissolved As, dissolved As(III) or dissolved As(V), respectively, in mol $\mathrm{L}^{-1}$. The exact HRT was calculated by dividing the experimental volume of water recovered from one channel by the flow rate (in $\mathrm{mL} \min ^{-1}$ ) measured at the channel inlet.

Nineteen days after the start of the experiment, the water was removed from the channels. The biogenic precipitates were recovered by scraping the biodegradable mesh with a sterilized spatula. The biogenic precipitate that covered the first section of the channel bottom $(0-50$ $\mathrm{cm}$, closest to inlet) was separated from that in the second section $(50-100 \mathrm{~cm}$, closest to 
outlet). The biogenic precipitates were collected into Falcon Tubes $(50 \mathrm{~mL})$ and centrifuged for $10 \mathrm{~min}$ at $4400 \times g$ (Sorwall ST40, Thermo Scientific). Sample from the first section (referred as Channel No X $-1^{\text {st }}$ section, abbreviated as $\mathrm{CX}-1^{\text {st }}$ ) was distributed into six aliquots: three for bacterial cell quantification, one for bacterial community analysis and aio $A$ gene quantification, one for As redox speciation and one for mineralogy determination. The second section (abbreviated as $\mathrm{CX}-2^{\text {nd }}$ ) yielded less biogenic precipitates and was distributed in two aliquots only, one for As redox speciation and one for the mineralogy analysis.

\subsection{Experimental monitoring}

\subsubsection{Chemical analyses}

Water samples were collected every third day at the channel inlets and outlets to monitor the main physico-chemical parameters ( $\mathrm{DO}$, temperature, $\mathrm{pH}$, conductivity and redox potential) and the rate of $\mathrm{Fe}$ (II) oxidation, together with $\mathrm{Fe}$ and $\mathrm{As}$ removal within the channels. Samples were filtered $(0.22 \mu \mathrm{m})$ and analyzed for dissolved Fe(II) by spectrophotometry, total dissolved Fe and As by ICP-MS (inductively coupled plasma-mass spectrometer), and As speciation by HPLC-ICP-MS (high performance liquid chromatography-ICP-MS). The biogenic precipitate was analyzed for total As and Fe content by ICP-MS after acid digestion

with aqua regia. Details of these analytical procedures are reported in Fernandez-Rojo et al. ${ }^{10}$ and in its supporting information file.

\subsubsection{Microbiological analyses}

Bacterial cell counting, DNA extraction and quantification of 16S rRNA genes and aioA genes were performed on the Reigous Creek original water used to feed the bioreactor, and on the biogenic precipitates ( $1^{\text {st }}$ section) recovered at the bottom of each channel at the end of the 
experiment, as described previously ${ }^{10}$. All DNA extractions were performed on triplicates. DNA extracts were quantified with a fluorometer (Qubit ${ }^{\circledR}$, Invitrogen) and stored at $-20{ }^{\circ} \mathrm{C}$ until further analysis.

The diversity and taxonomic composition of the bacterial communities of water and biogenic precipitates samples were determined by Illumina high-throughput sequencing of bacterial 16S rRNA genes. V4-V5 region (about 450 bases) was amplified by PCR using primers PCR1_515F ${ }^{19}$ and PCR1_928R ${ }^{20}$. The PCR products were sent to GeT-PlaGe platform (Toulouse, France) for Illumina MiSeq analysis using a $2 \times 300$ bp protocol. Bioinformatics analyses of $16 \mathrm{~S}$ rRNA gene sequences were performed with MOTHUR version $1.31^{21}$. Taxonomic affiliation was performed with a Bayesian classifier ${ }^{22}$ (using a $80 \%$ bootstrap confidence score) against the SILVA reference database v128. To homogenize the datasets the number of reads per sample was reduced to the lowest dataset by random selection (26000 reads). High quality sequences were then selected and clustered into operational taxonomic units (OTUs) using a 97\% cut-off. Diversity indices, rarefaction curves were calculated with MOTHUR at a level of $97 \%$ sequence similarity. The raw datasets are available on the EBI database system under project accession number [...]). Details of these analytical procedures are reported in Tardy et al. ${ }^{23}$

\subsubsection{Mineralogy and As speciation analyses}

Samples of the biogenic precipitates were kept under anaerobic conditions and dried under vacuum at room temperature. The As-bearing phases and the As redox state were determined by EXAFS (extended X-ray absorption fine structure) and XANES (X-ray absorption near edge structure), respectively, at the As K-edge. The Fe-bearing phases were determined only in $\mathrm{C} 1$ and $\mathrm{C} 4\left(1^{\text {st }}\right.$ and $2^{\text {nd }}$ section) by EXAFS at the Fe K-edge. The As and Fe K-edge 
EXAFS and XANES spectra were collected at $80 \mathrm{~K}$ in transmission mode on the XAFS beamline (ELETTRA, Trieste, Italy). Two scans were averaged for each sample, normalized and background subtracted over the $0-15 \AA^{-1} k$-range for As and over the $0-17 \AA^{-1} k$-range for Fe using the Athena Software ${ }^{24}$. Linear combination fitting (LCF) of the $k^{3}$-weighted EXAFS data was performed over the $3-15 \AA^{-1} k$-range for As and the $2-17 \AA^{-1} k$-range for Fe, with the same software. Detailed procedures are described in Fernandez-Rojo et al. ${ }^{10}$ and its supporting information file. LCF analysis of the XANES data was performed by Resongles et al. ${ }^{25}$ using an in-house program based on a Levenberg-Marquardt algorithm. As(III) and As(V) coprecipitated schwertmannites ${ }^{26}$ were used as model compounds.

\subsubsection{Statistical analyses}

The non-parametric Kruskal-Wallis test was used with a significance level of 0.05 in order to test whether $\mathrm{Fe}$ oxidation, $\mathrm{Fe}$ precipitation, As removal, bacterial cell concentration and aioA/16S gene ratio were statistically different between the four HRT. If the p-value of the Kruskal-Wallis test was lower than 0.05, Dunn's multiple comparison tests with Bonferroni pvalue adjustment were performed. Differences in bacterial composition between C1-74 min and C4-456 min were compared by one-way ANOVA, with a significance level of 0.05 . The statistical analyses were performed with the R free software (http://www.r-project.org/).

\section{Results}

\subsection{Treatment efficiency}

The mean chemical composition of the feed water at the inlet of each channel exhibited the typical characteristics of the Reigous Creek AMD ${ }^{7,27}$. The $\mathrm{pH}$ averaged 3.65, total dissolved 
Fe concentration averaged $480 \mathrm{mg} \mathrm{L}^{-1}(\sim 95 \% \mathrm{Fe}(\mathrm{II}))$ and total dissolved As concentration averaged $35 \mathrm{mg} \mathrm{L}^{-1}(\sim 17 \% \mathrm{As}(\mathrm{V}))$ (Table $\left.\mathrm{S} 1\right)$. The physico-chemical parameters and total dissolved $\mathrm{Fe}$ and As concentrations did not vary as much as $4 \%$ between the four channel inlets (Table S1), despite important difference in DO concentration (from 4 to $7 \mathrm{mg} \mathrm{L}^{-1}$ ). During the course of the experiment, inlet water parameters varied generally by less than 10\%, except DO and total dissolved As concentrations (36-42\%). The latter continuously decreased throughout experiment duration, due to precipitation in the feed tank, which equally impacted the four channel inlets.

Fe oxidation, Fe precipitation and As removal showed an upward trend with increasing HRT (Figure 1A); iron oxidation ranged from $10 \%$ in $\mathrm{C} 1-74$ min to $47 \%$ in $\mathrm{C} 4-456$ min (Figure 1B), Fe precipitation ranged from $9 \%$ in $\mathrm{C} 1$ to $22 \%$ in $\mathrm{C} 4$ (Figure 1C), and As removal ranged from $14 \%$ in $\mathrm{C} 1$ to $48 \%$ in $\mathrm{C} 4$ (Figure 1D). Efficiency was subjected to some temporal variation, as evidenced by dispersion of data in each boxplot. This could be related to the difficulty in maintaining a constant hydraulic retention time.

The outlet water chemistry varied accordingly to $\mathrm{Fe}$ oxidation, $\mathrm{Fe}$ precipitation and As removal between the channels (Figure 2). The most noteworthy changes from $\mathrm{C} 1-74$ to $\mathrm{C} 4-$ 456 min were associated to $\mathrm{pH}$ decrease, from 3.2 to 2.8 , dissolved $\mathrm{Fe}$ (II) concentration decrease (from 400 to $240 \mathrm{mg} \mathrm{L}^{-1}$ ), dissolved Fe(III) increase (from 30 to $120 \mathrm{mg} \mathrm{L}^{-1}$ ), and dissolved arsenic concentration (both $\mathrm{As}(\mathrm{III})$ and $\mathrm{As}(\mathrm{V})$ ) decrease, from 25 to $15 \mathrm{mg} \mathrm{\textrm {L } ^ { - 1 }}$ (Figure 2). 

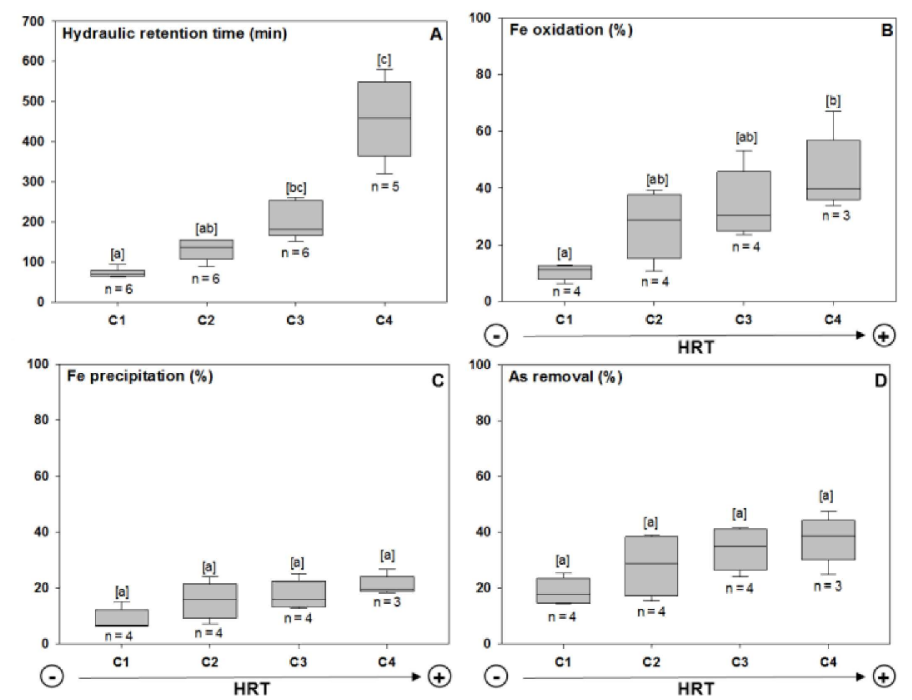

Figure 1. Boxplot representations of the HRT maintained on each channel for the whole duration of the experiment (A), and Fe oxidation (B), Fe precipitation (C) and As removal (D) at the steady-state. The vertical limits of the boxes represent the first and third quartiles and the line inside the box is the median. The extend of the whiskers shows the entire range of the data. Different letters in brackets indicate statistically significant differences between the groups ( $\mathrm{p}$-value $<0.05$ ) according to Kruskal-Wallis and Dunn's multiple comparison tests.
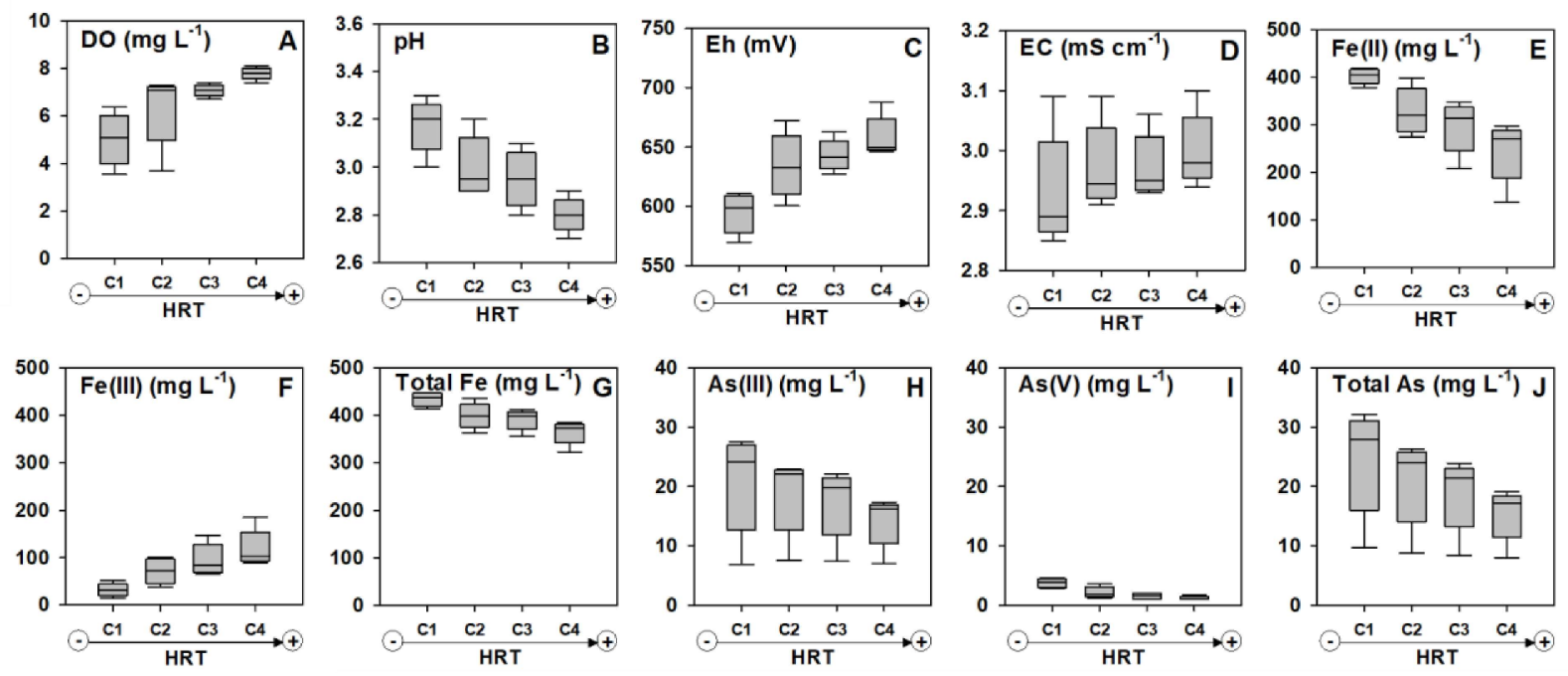

Figure 2. Boxplot representations of dissolved oxygen (DO) (A), pH (B), redox potential (Eh) (C), electrical conductivity (EC) (D), Fe(II) (E), Fe(III) (F), total Fe (G), As(III) (H), As(V) (I) and total As (J) determined in the outlet water. Representation of data as boxplots as described for Figure 1. 


\subsection{Arsenic speciation and mineralogy of the biogenic precipitates}

The biogenic precipitates contained an average of $71 \pm 13 \mathrm{mg} \mathrm{g}^{-1}$ of As, and $366 \pm 11 \mathrm{mg} \mathrm{g}^{-1}$ of Fe (Table 1). The As/Fe molar ratio decreased with increasing HRT (0.2 to 0.1 from $\mathrm{C} 1$ to C4), and from the first section to the second section of the channels (Table 1, Figure 3).

As-XANES LCF indicated that arsenic was mainly in the form of As(III) ( $\geq 65 \%$ ). AsEXAFS LCF showed that arsenic was mainly distributed between two distinct solid phases, with little variation among samples: As(III) sorbed to schwertmannite (68 to $82 \%$ ), and As(V) in amorphous ferric arsenate (18 to $32 \%$ ) (Table 1, Figure 3A). Fe-EXAFS LCF indicated that iron was predominantly in schwertmannite $(64-91 \%)$ and, to a lower extent, in amorphous ferric arsenate $(9-36 \%)$ (Figure 3B). The proportion of schwertmannite was slightly higher in the second section of the channels than in the first one.
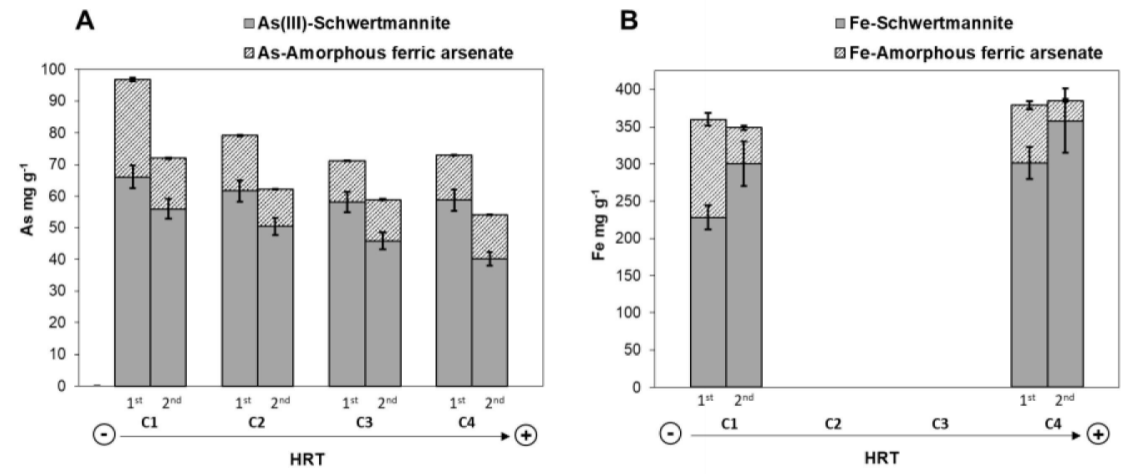

Figure 3. Arsenic (A) and iron (B) solid speciation derived from LCF analysis of EXAFS spectra collected at the As and $\mathrm{Fe} \mathrm{K}$-edges on the biogenic precipitates in the $1^{\text {st }}$ and $2^{\text {nd }}$ section of the channels. Corresponding experimental and LCF spectra are displayed in Figure S1 and Figure S2, respectively. LCF results are reported in Table S2

and

Table

S3, respectively. 


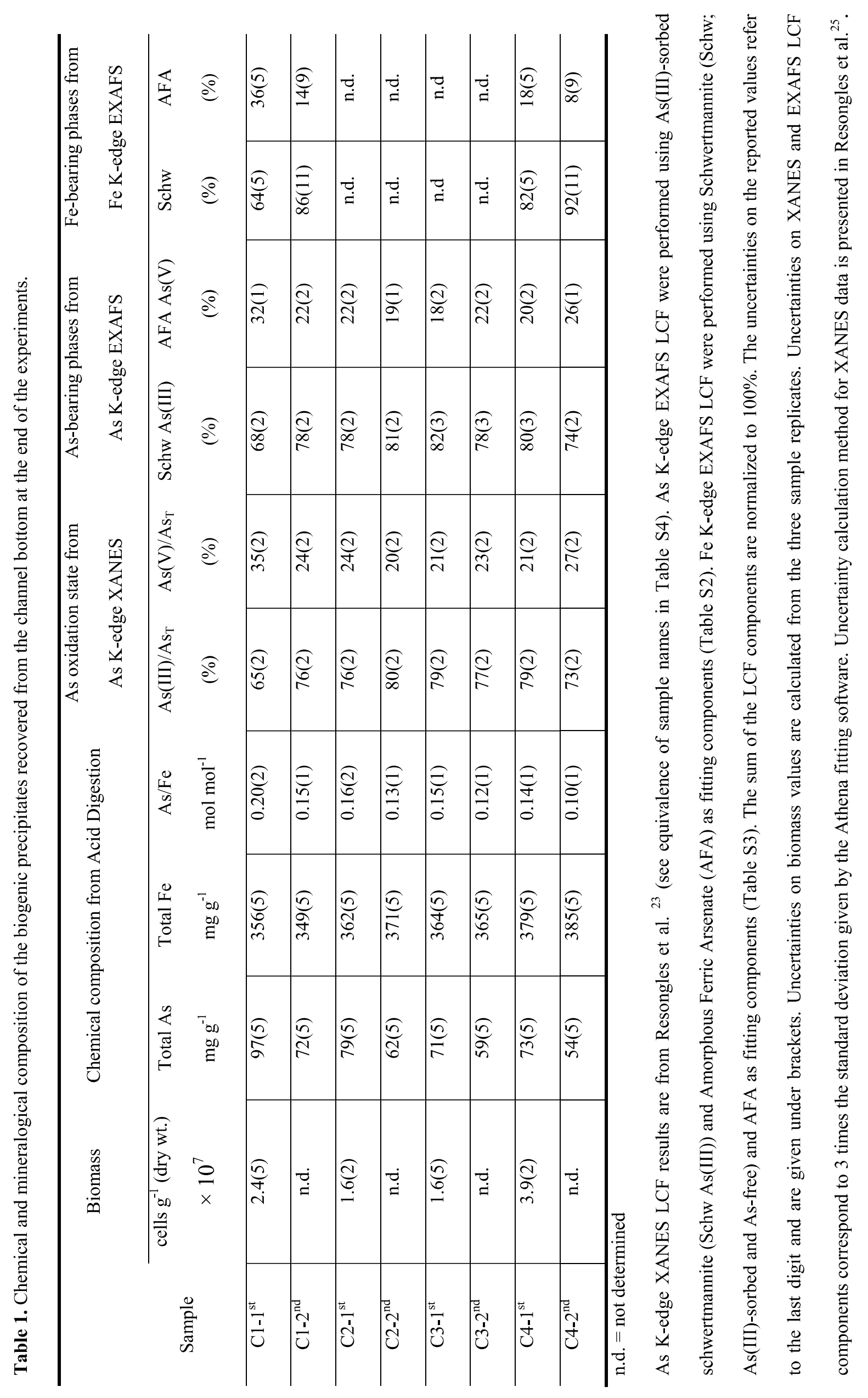




\subsection{Microbiological characterization of feed water and biogenic precipitates}

\subsubsection{Bacterial cell concentration}

Feed water collected from the source of the Reigous Creek contained $5 \times 10^{5}$ bacterial cells $\mathrm{mL}^{-1}$. In the biogenic precipitate, the average bacterial cell concentration was $2 \pm$ $1 \times 10^{7}$ bacterial cells $\mathrm{g}^{-1}$ (dry wt.), without significant differences between the HRT (Table 1).

\subsubsection{Bacterial diversity}

High-throughput sequencing yielded a total of 429004 sequences of 16S rRNA gene corresponding to 26000 quality sequences per sample, which adequately covered the bacterial diversity in all the experiments (Figure S3). Bacterial communities developed in the biogenic precipitates exhibited lower levels of diversity compared to those from the feed water, as evidenced by lower diversity indexes (richness, evenness and Shannon) (Table S5). No clear difference was observed between the channels. In agreement with diversity indices, the bacterial composition in the biogenic precipitates was characterized by the dominance of a relative small number of bacterial OTU (Figure 4). The two most important OTU were affiliated with Ferrovum and Gallionella genera, representing $31 \%$ and $36 \%$ of the whole dataset sequences, respectively. In the feed water, a much higher richness of OTUs was identified (Table S5). The majority of these OTUs represented less than $1 \%$ of the whole dataset each in term of number of sequences, and were thus referred as "other groups". Unclassified bacteria were the second most abundant group, followed by Sphyngopyxis and Gallionella with a proportion of less than $10 \%$ each. 
Application of different HRT strongly impacted the bacterial community structure and composition in the biogenic precipitates (Figure 4). According to the performed ANOVA tests, increasing HRT resulted in a significant increase of the proportion of bacteria affiliated to Ferrovum genus (from 12 to $51 \%$ of total sequences), Candidatus Captivus genus (from 0.1 to $4 \%$ of total sequences) and Acidocella genus (from 0.1 to $3 \%$ of total sequences). Conversely, significant decrease was observed for the bacteria affiliated with Gallionella (from $65 \%$ to $23 \%$ of total sequences), Legionella (from 4 to $0.1 \%$ of total sequences) and Thiomonas (from 3 to $2 \%$ of total sequences) genera. No effect of HRT was observed for the iron-oxidizing bacteria affiliated with Acidithiobacillus and Sideroxydans genera.

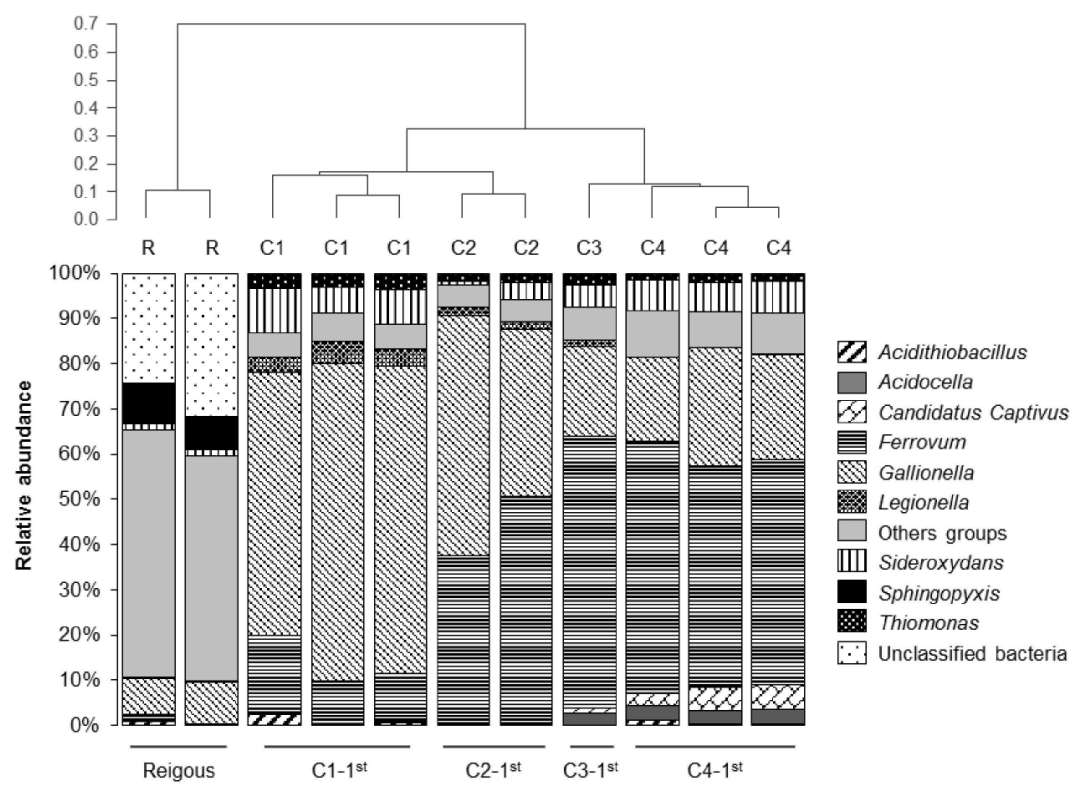

Figure 4. Relative abundance of bacterial genera in Reigous water $(\mathrm{R})$ and in biogenic precipitates formed in the bottom of the channel under different HRT (C1: $74 \mathrm{~min}$; $\mathrm{C} 2: 130 \mathrm{~min}$; $\mathrm{C} 3: 200 \mathrm{~min}$; $\mathrm{C} 4$ : $456 \mathrm{~min}$ ). Cluster tree represents the phylogenetic community distance based on the operational taxonomic unit (OTU) composition. "Other groups" represent the phylogenetic groups (genus) with a relative abundance $<1 \%$ calculated on the whole dataset. 


\subsubsection{Functional potential of arsenic oxidation}

The biogenic precipitates exhibited higher aioA/16S rRNA gene ratio (average 0.13 to 0.40) than the feed water from Reigous Creek (0.03). Difference between HRT was not significant (Figure 5).

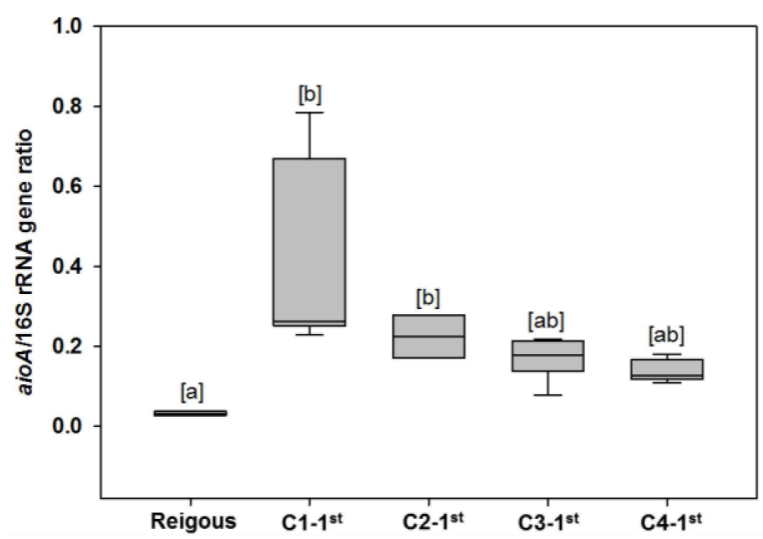

Figure 5. aio $A / 16 \mathrm{~S}$ rRNA gene ratio in the Reigous water and in the biogenic precipitates at the end of the experiment at different HRT. Letters in brackets indicate significant differences between treatments, according to Kruskal-Wallis (p-value $<0.05$ ) and Dunn's multiple comparison tests.

\section{Discussion}

\subsection{Bioreactor performance and biogenic precipitates composition}

Increasing the HRT improved the performance of the bioreactor in terms of Fe(II) oxidation and As abatement (Figure 1D). However, performances were lower than in our previous study ${ }^{10}$. Fe(II) oxidation and As removal reached respectively $\sim 50 \%$ and $\sim 40 \%$ for the highest HRT (456 min), whereas in our previous study ${ }^{10}$, these efficiencies were higher than $80 \%$ (Fe(II) oxidation) and $60 \%$ (As removal) at HRT $=$ 
$500 \mathrm{~min}$, in the same operating conditions. The difference may be attributed to higher $\mathrm{pH}$ of the AMD water in the present experiment $(\mathrm{pH}=3.65)$ compared to the previous ones $(\mathrm{pH}=3.0$ to 3.4 ). In $\mathrm{AMD}$, lower $\mathrm{pH}$ promotes fastest rates of biological $\mathrm{Fe}(\mathrm{II})$ oxidation, coinciding with the higher Fe(III) solubility ${ }^{28}$. Furthermore, the lower proportion of $\mathrm{As}(\mathrm{V})$ in the feed water $(17 \%$, Table $\mathrm{S} 1)$ compared to the previous study $(\mathrm{As}(\mathrm{V})=17-39 \%){ }^{10}$ did not favor As retention in the biogenic precipitates. Indeed, $\mathrm{As}(\mathrm{V})-\mathrm{Fe}(\mathrm{III})$ solids forming in AMDs are known to be about ten times less soluble than As(III)-Fe(III) phases $^{26}$.

Increasing the HRT decreased the $\mathrm{As} / \mathrm{Fe}$ ratio in the biogenic precipitate (Table 1; Figure 3) but did not affect significantly the redox state of arsenic in the solid and the distribution of As-bearing phases. The biogenic precipitates were mainly composed of As(III)-sorbed and As-free schwertmannite, accompanied with minor amounts of As(V)-bearing amorphous ferric arsenate, both phases being typical of AMD systems containing arsenic ${ }^{29,30}$, including in the Reigous Creek in Carnoulès ${ }^{7,31}$. Amorphous ferric arsenate has been shown to form in acid sulfate solution with initial dissolved $\mathrm{As}(\mathrm{V}) / \mathrm{Fe}(\mathrm{III})$ molar ratios higher than $0.15-0.2$, while As(V)-sorbed schwertmannite formed at lower $\mathrm{As}(\mathrm{V}) / \mathrm{Fe}(\mathrm{III})$ molar ratios ${ }^{26,32}$. In the present experiments, the dissolved $\mathrm{As}(\mathrm{V}) / \mathrm{Fe}(\mathrm{III})$ molar ratio varied from $0.2 \pm 0.1$ in the feed water to $0.1 \pm 0.1$, during the oxidation of $\mathrm{Fe}(\mathrm{II})$ to Fe(III) in the channels. These ratios are consistent with the presence of amorphous ferric arsenate in the biogenic precipitates. In our experimental pilot system, no tooeleite was detected, whereas this mineral is usually found in Reigous Creek ${ }^{31}$. Maillot et al. ${ }^{26}$ observed the formation of amorphous ferric arsenite at initial dissolved $\mathrm{As}(\mathrm{III}) / \mathrm{Fe}(\mathrm{III})$ molar ratio above 0.6, and $\mathrm{As}(\mathrm{III})$-sorbed schwertmannite below this ratio. Here, the dissolved $\mathrm{As}(\mathrm{III}) / \mathrm{Fe}(\mathrm{III})$ molar ratio varied 
from $1.0 \pm 0.7$ in the feed water to $0.5 \pm 0.7$, during Fe(II) oxidation. In these conditions, the nucleation of schwertmannite is faster than that of amorphous ferric arsenite or nanocrystalline tooeleite, as shown in the study from Egal et al. ${ }^{33}$.

\subsection{Influence of the HRT on bacterial communities}

\subsubsection{Iron-oxidizing bacteria}

The most abundant OTUs found in the biogenic precipitates established at the bottom of the channels were the iron-oxidizing Betaproteobacteria related to the Ferrovum and Gallionella genera. These bacteria have been commonly observed in natural AMD ${ }^{34-36}$ and in bioreactors for the treatment of acid mine waters ${ }^{37-39}$. Gallionella dominated the water bacterial community in most of the stations along the Carnoulès AMD whatever the season while Ferrovum were less abundant particularly in the upstream more contaminated stations ${ }^{35}$.

The HRT clearly exerted an effect on bacterial community distribution, especially the relative contribution of Gallionella and Ferrovum. Several factors can explain this effect. Many studies highlighted $\mathrm{pH}$ as the most important factor structuring AMD communities ${ }^{14,15,40}$. In our experiment, the outlet $\mathrm{pH}$ was lower (2.8) when the highest HRT was applied. Jones et al. ${ }^{36}$ analyzed the composition of sediment communities from the Red Eyes drainage (USA) and found that Gallionella-like organisms were restricted to locations with a $\mathrm{pH}>3$, whereas Ferrovum dominated at $\mathrm{pH}<3$. Similarly, in a bioreactor for the treatment of acid mine drainage, Heinzel et al. ${ }^{37}$ reported a shift in the dominant species of the bacterial community from Ferrovum relatives to Gallionella relatives when the $\mathrm{pH}$ increased from 3.0 to 3.4 and the ferric iron concentration decreased from $\sim 105$ to $\sim 30 \mathrm{mg} \mathrm{L}^{-1}$. Hallberg ${ }^{41}$ indicated that apart from 
$\mathrm{pH}$ and temperature (constant in our bioreactor), there are more subtle factors such as the affinity for electron acceptors (e.g. oxygen), that could drive the structure of the microbial communities. In this respect, Gallionella is a microaerophilic bacterium that normally grows at $0.1-1 \mathrm{mg} \mathrm{L}^{-1} \mathrm{DO}^{42}$ while Ferrovum myxofaciens, the only species of Ferrovum described to date, is a strict aerobe bacterium ${ }^{43}$. Such sensitivity to DO concentration might explain the change from Gallionella to Ferrovum while DO increased from $5 \mathrm{mg} \mathrm{L}^{-1}$ (outlet DO) in $\mathrm{C} 1-74 \mathrm{~min}$ (Figure 2) to $7.8 \mathrm{mg} \mathrm{L}^{-1}$ (outlet DO) in C4-456 min. In a similar way, Fabisch et al. ${ }^{44}$ observed that Ferrovum increased by 10-fold along the flow path of a metal rich mine discharge, presumably due to increasing oxygen content, from $0.8-4.1 \mathrm{mg} \mathrm{L}^{-1}$, in the outflow, to $5.5-9.7 \mathrm{mg} \mathrm{L}^{-1}$ at the most oxygenated site. However, the optimal oxygen conditions of Ferrovum sp. have not been well defined yet and some contradictory results have been found ${ }^{45}$.

\subsubsection{Arsenite-oxidizing bacteria}

The detection of aioA genes and 16S rRNA sequences affiliated with Thiomonas spp. in the biogenic precipitates shows that the bacteria having the potential to oxidize arsenic are present in the bioreactor. However, arsenic in the biogenic precipitates was preferentially trapped in the form of As(III) for all the HRT, and outlet water also contained predominantly dissolved As(III) (> $82 \%)$. This suggests that As oxidation was not favored in this experiment. Bacteria belonging to the Thiomonas genus were shown to be active in situ in the Carnoulès AMD ${ }^{46}$, and to actively express the enzyme arsenite oxidase although they were not a major member of the bacterial community ${ }^{47}$. They were also able to oxidize arsenic under laboratory conditions ${ }^{48,49}$. The apparent lack of expression of $\mathrm{As}(\mathrm{III})$ oxidizing activity in the present experiment remains 
unexplained. The regulation of the expression of arsenite oxidation genetic potential among Thiomonas strains appears to be complex and is not fully understood.

The As-oxidizing activity of Thiomonas may be modulated by the physico-chemistry of the AMD. In the present study, the original AMD pH was 4.7 but decreased to 3.65 under laboratory storage. The growth rate of the arsenite-oxidizing 'Thiomonas arsenivorans' was reduced to half as the starting $\mathrm{pH}$ decreased from 4.0 to $\sim 3.5$ in batch cultures on a synthetic medium containing $100 \mathrm{mg} \mathrm{L}^{-1} \mathrm{As}(\mathrm{III})^{50}$. In similar experiments, Battaglia-Brunet et al. ${ }^{51}$ observed that the arsenite oxidation rate of the consortium $\mathrm{CAsO}_{1}$, which contained 'Thiomonas arsenivorans', decreased (from $\sim 2.15$ to $\sim 1.65$ $\left.\mathrm{mg} \mathrm{L}^{-1} \mathrm{~h}^{-1}\right)$ with $\mathrm{pH}$ change from 4 to 3 , and even further at $\mathrm{pH} 2\left(<0.25 \mathrm{mg} \mathrm{L}^{-1} \mathrm{~h}^{-1}\right)$. The bacterial growth followed the same trend. The $\mathrm{pH}$ decrease in the feed water under laboratory storage, regardless the HRT, is a potential reason for the lack of As oxidation. However, identification of the regulation factors deserves further research.

\subsubsection{Other bacteria}

The proportion of Acidocella sp., an iron-reducing heterotrophic acidophilic microorganism, increased with increasing HRT, while the outlet $\mathrm{pH}$ decreased from 3.2 to 2.8. This trend was opposite to that observed in flow-through bioreactors inoculated with sediments from Brubaker Run, in the Appalachian bituminous coal basin, that showed a decrease of Acidocella sp. abundance with decreasing $\mathrm{pH}$ from 4.2 to $3.3^{38}$. Most probably, the increase of the proportion of Acidocella sp. in our study can be linked to increasing Fe(III) concentration with increasing HRT. It can be hypothesized that this bacterium thrives in conditions where precipitation of $\mathrm{Fe}(\mathrm{III})$ is limited by low $\mathrm{pH}$ values. 
Legionella is a non-iron-oxidizing heterotrophic bacterium that is relatively uncommon in AMD. However, it has been reported in AMD of the Xiang Mountain sulfide mine 52,53 and was a dominant member of the bacterial community in a tailings pond from a metal mine ${ }^{54}$. The presence of this bacterium has been attributed to its association with eukaryotic cells that colonize AMD. Similarly, Candidatus Captivus is an endosymbiont of protist cells that has been previously observed in AMD from Iron Mountain ${ }^{55}$. However, as we did not analyze the eukaryotic community in the present experiment, the higher abundance of Legionella and Candidatus Captivus at lower and higher HRT, respectively, cannot be related to eukaryotes dynamics.

\subsection{Environmental significance}

The present study confirmed the capacity of our lab-scale channel bioreactor to immobilize arsenic from AMD. This capacity was ascribed to the ability of autochthonous iron-oxidizing bacteria Gallionella and Ferrovum, present in the original AMD seed water, to oxidize iron at acid $\mathrm{pH}$. Although HRT influenced the structure and composition of the bacterial community that settled in the bioreactor, these bacteria remained dominant members of the community at all HRT values. Such robustness is a key factor for future field-scale application of this treatment. Nevertheless, long-term monitoring of bacterial community during longer bioreactor operation would be required to confirm this stability. Early results from other flow-through bioreactors treating AMD suggest that despite some changes in the microbial community during long-term operation, the biological Fe(II)-oxidizing performance was maintained ${ }^{38,56}$, which further demonstrated the reliability of this kind of bioreactor for the oxidation of $\mathrm{Fe}(\mathrm{II})$ in AMD treatments. 
Although arsenic abatement increased substantially with HRT, a maximum of $40 \%$ As removal was reached at HRT of $\sim 500 \mathrm{~min}$, which contrasted with the $\sim 80 \%$ As removal in previous experiments ${ }^{10}$. Contrary to the present study, in these earlier experiments As(III) oxidation occurred within the bioreactor, thus improving As removal efficiency. As discussed previously (Section 4.2.2), the factors that regulate arsenite oxidation activity in our bioreactor remain to be deciphered. The importance of such regulation is also crucial regarding the stability of As-bearing solid phases that form during the treatment. Indeed, the dominant phase in the channel bioreactor was As(III)-bearing schwertmannite, with low proportion of amorphous ferric arsenate. As(III)-bearing schwertmannite is a metastable precursor leading to jarosite or goethite while releasing arsenic in the dissolved phase during aging ${ }^{57}$. Conversely, ferric arsenate phases were shown to be the most suitable for safe disposal ${ }^{58}$.

\section{Associated content}

Supporting information

The supporting information section contains Tables S1-S5 and Figures S1-S3.

\section{Author information}

Corresponding author: Corinne Casiot

Email: casiot@msem.univ-montp2.fr

Phone: +33467143356 


\section{Acknowledgements}

The authors thank the IngECOST-DMA project (ANR-13-ECOT-0009), the OSU OREME (SO POLLUMINE Observatory, funded since 2009) and the Ecole Doctorale GAIA (PhD fellowship of Lidia Fernandez-Rojo, 2014-2017) for the financial support. We thank Remi Freydier for ICP-MS analysis on the AETE-ISO platform (OSU OREME, University of Montpellier). We thank Christophe Duperray, from the Montpellier RIO Imaging microscopy platform, for his kind assistance in cytometry. Mickaël Charron from BRGM it is gratefully acknowledged for its technical assistance on aioA gene quantification. We also thank Luca Olivi from the XAFS beamline at the ELETTRA synchrotron (Trieste, Italy). 


\section{References}

(1) Williams, M. Arsenic in mine waters: an international study. Environ. Geol. 2001, 40 (3), 267-278.

(2) Paikaray, S. Arsenic geochemistry of acid mine drainage. Mine Water Environ. 2015, 34 (2), 181-196.

(3) Battaglia-Brunet, F.; Itard, Y.; Garrido, F.; Delorme, F.; Crouzet, C.; Greffie, C.; Joulian, C. A simple biogeochemical process removing arsenic from a mine drainage water. Geomicrobiol. J. 2006, 23 (3-4), 201-211.

(4) Elbaz-Poulichet, F.; Bruneel, O.; Casiot, C. The Carnoulès mine. Generation of As-rich acid mine drainage, natural attenuation processes and solutions for passive in-situ remediation. In Difpolmine (Diffuse Pollution From Mining Activities); 2006.

(5) Macías, F.; Caraballo, M. A.; Nieto, J. M.; Rötting, T. S.; Ayora, C. Natural pretreatment and passive remediation of highly polluted acid mine drainage. $J$. Environ. Manage. 2012, 104 (0), 93-100.

(6) Asta, M. P.; Ayora, C.; Román-Ross, G.; Cama, J.; Acero, P.; Gault, A. G.; Charnock, J. M.; Bardelli, F. Natural attenuation of arsenic in the Tinto Santa Rosa acid stream (Iberian Pyritic Belt, SW Spain): The role of iron precipitates. Chem. Geol. 2010, 271 (1-2), 1-12.

(7) Egal, M.; Casiot, C.; Morin, G.; Elbaz-Poulichet, F.; Cordier, M.-A.; Bruneel, O. An updated insight into the natural attenuation of As concentrations in Reigous Creek (southern France). Appl. Geochemistry 2010, 25 (12), 1949-1957. 
(8) Ohnuki, T.; Sakamoto, F.; Kozai, N.; Ozaki, T.; Yoshida, T.; Narumi, I.; Wakai, E.; Sakai, T.; Francis, A. J. Mechanisms of arsenic immobilization in a biomat from mine discharge water. Chem. Geol. 2004, 212 (3-4), 279-290.

(9) Modis, K.; Adam, K.; Panagopoulos, K.; Kontopoulos, A. Development and Validation of a geostatistical model for prediction of acid mine drainage in underground sulphide mines. In Transactions - Institution of Mining and Metallurgy. Section A. Mining Industry; Institution of Mining \& Metallurgy, 1998; Vol. 107, pp A102-A107.

(10) Fernandez-Rojo, L.; Héry, M.; Le Pape, P.; Braungardt, C.; Desoeuvre, A.; Torres, E.; Tardy, V.; Resongles, E.; Laroche, E.; Delpoux, S.; et al. Biological attenuation of arsenic and iron in a continuous flow bioreactor treating acid mine drainage (AMD). Water Res. 2017, 123, 594-606.

(11) Vasquez, Y.; Escobar, M. C.; Neculita, C. M.; Arbeli, Z.; Roldan, F. Biochemical passive reactors for treatment of acid mine drainage: Effect of hydraulic retention time on changes in efficiency, composition of reactive mixture, and microbial activity. Chemosphere 2016, 153, 244-253.

(12) Vasquez, Y.; Escobar, M. C.; Saenz, J. S.; Quiceno-Vallejo, M. F.; Neculita, C. M.; Arbeli, Z.; Roldan, F. Effect of hydraulic retention time on microbial community in biochemical passive reactors during treatment of acid mine drainage. Bioresour. Technol. 2018, 247 (4), 624-632.

(13) Lear, G.; Niyogi, D.; Harding, J.; Dong, Y.; Lewis, G. Biofilm bacterial community structure in streams affected by acid mine drainage. Appl. Environ. Microbiol. 2009, 75 (11), 3455-3460. 
(14) Kuang, J.-L.; Huang, L.-N.; Chen, L.-X.; Hua, Z.-S.; Li, S.-J.; Hu, M.; Li, J.-T.; Shu, W.-S. Contemporary environmental variation determines microbial diversity patterns in acid mine drainage. ISME J. 2013, 7 (5), 1038-1050.

(15) Chen, L.; Li, J.; Chen, Y.; Huang, L.; Hua, Z.; Hu, M.; Shu, W. Shifts in microbial community composition and function in the acidification of a lead/zinc mine tailings. Environ. Microbiol. 2013, 15 (9), 2431-2444.

(16) Edwards, K. J.; Gihring, T. M.; Banfield, J. F. Seasonal variations in microbial populations and environmental conditions in an extreme acid mine drainage environment. Appl. Environ. Microbiol. 1999, 65 (8), 3627-3632.

(17) González-Toril, E.; Aguilera, A.; Souza-Egipsy, V.; López Pamo, E.; Sánchez España, J.; Amils, R. Geomicrobiology of La Zarza-Perrunal acid mine effluent (Iberian Pyritic Belt, Spain). Appl. Environ. Microbiol. 2011, 77 (8), 2685-2694.

(18) Cheng, H.; Hu, Y.; Luo, J.; Xu, B.; Zhao, J. Geochemical processes controlling fate and transport of arsenic in acid mine drainage (AMD) and natural systems. $J$ Hazard Mater 2009, 165 (1-3), 13-26.

(19) Barret, M.; Briand, M.; Bonneau, S.; Préveaux, A.; Valière, S.; Bouchez, O.; Hunault, G.; Simoneau, P.; Jacquesa, M.-A. Emergence shapes the structure of the seed microbiota. Appl. Environ. Microbiol. 2015, 81 (4), 1257-1266.

(20) Wang, Y.; Qian, P.-Y. Conservative fragments in bacterial 16S rRNA genes and primer design for $16 \mathrm{~S}$ ribosomal DNA amplicons in metagenomic studies. PLoS One 2009, 4 (10), e7401.

(21) Schloss, P. D.; Westcott, S. L.; Ryabin, T.; Hall, J. R.; Hartmann, M.; Hollister, 
E. B.; Lesniewski, R. A.; Oakley, B. B.; Parks, D. H.; Robinson, C. J.; et al. Introducing mothur: Open-source, platform-independent, community-supported software for describing and comparing microbial communities. Appl. Environ. Microbiol. 2009, 75 (23), 7537-7541.

(22) Wang, Q.; Garrity, G. M.; Tiedje, J. M.; Cole, J. R. Naive Bayesian classifier for rapid assignment of rRNA sequences into the new bacterial taxonomy. Appl. Environ. Microbiol. 2007, 73 (16), 5261-5267.

(23) Tardy, V.; Casiot, C.; Fernandez-Rojo, L.; Resongles, E.; Desoeuvre, A.; Joulian, C.; Battaglia-Brunet, F.; Héry, M. Temperature and nutrients as drivers of microbially mediated arsenic oxidation and removal from acid mine drainage. Appl. Microbiol. Biotechnol. 2018, 1-12.

(24) Ravel, B.; Newville, M. ATHENA , ARTEMIS , HEPHAESTUS : data analysis for X-ray absorption spectroscopy using IFEFFIT. J. Synchrotron Radiat. 2005, 12 (4), 537-541.

(25) Resongles, E.; Le Pape, P.; Fernandez-Rojo, L.; Morin, G.; Brest, J.; Guo, S.; Casiot, C. Routine determination of inorganic arsenic speciation in precipitates from acid mine drainage using orthophosphoric acid extraction followed by HPLC-ICP-MS. Anal. Methods 2016, 8, 7420-7426.

(26) Maillot, F.; Morin, G.; Juillot, F.; Bruneel, O.; Casiot, C.; Ona-Nguema, G.; Wang, Y.; Lebrun, S.; Aubry, E.; Vlaic, G.; et al. Structure and reactivity of As(III)- and As(V)-rich schwertmannites and amorphous ferric arsenate sulfate from the Carnoulès acid mine drainage, France: Comparison with biotic and abiotic model compounds and implications for As remediation. Geochim. 
Cosmochim. Acta 2013, 104, 310-329.

(27) Casiot, C.; Morin, G.; Juillot, F.; Bruneel, O.; Personné, J.-C.; Leblanc, M.; Duquesne, K.; Bonnefoy, V.; Elbaz-Poulichet, F. Bacterial immobilization and oxidation of arsenic in acid mine drainage (Carnoulès creek, France). Water Res. 2003, 37 (12), 2929-2936.

(28) Larson, L. N.; Sánchez-España, J.; Kaley, B.; Sheng, Y.; Bibby, K.; Burgos, W. D. Thermodynamic controls on the kinetics of microbial low-pH Fe(II) oxidation. Environ. Sci. Technol. 2014, 48 (16), 9246-9254.

(29) Fukushi, K.; Sasaki, M.; Sato, T.; Yanase, N.; Amano, H.; Ikeda, H. A natural attenuation of arsenic in drainage from an abandoned arsenic mine dump. Appl. Geochemistry 2003, 18 (8), 1267-1278.

(30) Courtin-Nomade, A.; Grosbois, C.; Bril, H.; Roussel, C. Spatial variability of arsenic in some iron-rich deposits generated by acid mine drainage. Appl. Geochemistry 2005, 20 (2), 383-396.

(31) Morin, G.; Juillot, F.; Casiot, C.; Bruneel, O.; Personné, J.-C.; Elbaz-Poulichet, F.; Leblanc, M.; Ildefonse, P.; Calas, G. Bacterial formation of tooeleite and mixed arsenic(III) or arsenic(V)-iron(III) gels in the Carnoulès acid mine drainage, France. A XANES, XRD, and SEM study. Environ. Sci. Technol. 2003, 37 (9), 1705-1712.

(32) Carlson, L.; Bigham, J. M.; Schwertmann, U.; Kyek, A.; Wagner, F. Scavenging of As from acid mine drainage by schwertmannite and ferrihydrite: a comparison with synthetic analogues. Env. Sci Technol 2002, 36 (8), 1712-1719. 
(33) Egal, M.; Casiot, C.; Morin, G.; Parmentier, M.; Bruneel, O.; Lebrun, S.; ElbazPoulichet, F. Kinetic control on the formation of tooeleite, schwertmannite and jarosite by Acidithiobacillus ferrooxidans strains in an As(III)-rich acid mine water. Chem. Geol. 2009, 265 (3-4), 432-441.

(34) Kimura, S.; Bryan, C. G.; Hallberg, K. B.; Johnson, D. B. Biodiversity and geochemistry of an extremely acidic, low-temperature subterranean environment sustained by chemolithotrophy. Environ. Microbiol. 2011, 13 (8), 2092-2104.

(35) Volant, A.; Bruneel, O.; Desoeuvre, A.; Héry, M.; Casiot, C.; Bru, N.; Delpoux, S.; Fahy, A.; Javerliat, F.; Bouchez, O.; et al. Diversity and spatiotemporal dynamics of bacterial communities: physicochemical and other drivers along an acid mine drainage. FEMS Microbiol. Ecol. 2014, 90 (1), 247-263.

(36) Jones, D. S.; Kohl, C.; Grettenberger, C.; Larson, L. N.; Burgos, W. D.; Macaladya, J. L. Geochemical niches of iron-oxidizing acidophiles in acidic coal mine drainage. Appl. Environ. Microbiol. 2015, 81 (4), 1242-1250.

(37) Heinzel, E.; Janneck, E.; Glombitza, F.; Schlömann, M.; Seifert, J. Population dynamics of iron-oxidizing communities in pilot plants for the treatment of acid mine waters. Environ. Sci. Technol. 2009, 43 (16), 6138-6144.

(38) Sheng, Y.; Bibby, K.; Grettenberger, C.; Kaley, B.; Macalady, J. L.; Wang, G.; Burgos, W. D. Geochemical and temporal influences on the enrichment of acidophilic iron-oxidizing bacterial communities. Appl. Environ. Microbiol. 2016, 82 (12), 3611-3621.

(39) Sun, W.; Xiao, E.; Kalin, M.; Krumins, V.; Dong, Y.; Ning, Z.; Liu, T.; Sun, M.; 
Zhao, Y.; Wu, S.; et al. Remediation of antimony-rich mine waters: Assessment of antimony removal and shifts in the microbial community of an onsite fieldscale bioreactor. Environ. Pollut. 2016, 215, 213-222.

(40) Teng, W.; Kuang, J.; Luo, Z.; Shu, W. Microbial diversity and community assembly across environmental gradients in acid mine drainage. Minerals 2017, 7 (6), 106.

(41) Hallberg, K. B. New perspectives in acid mine drainage microbiology. Hydrometallurgy 2010, 104 (3-4), 448-453.

(42) Hanert, H. H. The genus Gallionella. In The Prokaryotes; Springer New York: New York, NY, 2006; pp 990-995.

(43) Johnson, D. B.; Hallberg, K. B.; Hedrich, S. Uncovering a microbial enigma: isolation and characterization of the streamer-generating, iron-oxidizing, acidophilic bacterium Ferrovum myxofaciens. Appl. Environ. Microbiol. 2014, 80 (2), 672-680.

(44) Fabisch, M.; Freyer, G.; Johnson, C. A.; Büchel, G.; Akob, D. M.; Neu, T. R.; Küsel, K. Dominance of "Gallionella capsiferriformans" and heavy metal association with Gallionella-like stalks in metal-rich pH 6 mine water discharge. Geobiology 2016, 14 (1), 68-90.

(45) Jwair, R. J.; Tischler, J. S.; Janneck, E.; Schlömann, M. Acid mine water treatment using novel acidophilic iron-oxidizing bacteria of the genus "Ferrovum": effect of oxygen and carbon dioxide on survival. In Mining Meets Water-Conflicts and Solutions; Drebenstedt, C., Paul, M., Eds.; 2016; pp 1060- 
1063.

(46) Bruneel, O.; Volant, A.; Gallien, S.; Chaumande, B.; Casiot, C.; Carapito, C.; Bardil, A.; Morin, G.; Brown Jr., G. E.; Personné, J. C.; et al. Characterization of the active bacterial community involved in natural attenuation processes in arsenic-rich creek sediments. Microb Ecol 2011, 61 (4), 793-810.

(47) Hovasse, A.; Bruneel, O.; Casiot, C.; Desoeuvre, A.; Farasin, J.; Hery, M.; Van Dorsselaer, A.; Carapito, C.; Arsène-Ploetze, F. Spatio-temporal detection of the Thiomonas population and the Thiomonas arsenite oxidase involved in natural arsenite attenuation processes in the Carnoulès acid mine drainage. Front. cell Dev. Biol. 2016, 4 (3), 1-14.

(48) Bruneel, O.; Personné, J. C.; Casiot, C.; Leblanc, M.; Elbaz-Poulichet, F.; Mahler, B. J.; Le Flèche, A.; Grimont, P. A. D. Mediation of arsenic oxidation by Thiomonas sp. in acid-mine drainage (Carnoulès, France). J. Appl. Microbiol. 2003, 95 (3), 492-499.

(49) Duquesne, K.; Lieutaud, A.; Ratouchniak, J.; Muller, D.; Lett, M.-C.; Bonnefoy, V. Arsenite oxidation by a chemoautotrophic moderately acidophilic Thiomonas sp.: from the strain isolation to the gene study. Environ. Microbiol. 2008, 10 (1), $228-237$.

(50) Battaglia-Brunet, F.; Joulian, C.; Garrido, F.; Dictor, M.-C.; Morin, D.; Coupland, K.; Barrie Johnson, D.; Hallberg, K. B.; Baranger, P. Oxidation of arsenite by Thiomonas strains and characterization of Thiomonas arsenivorans sp. nov. Antonie Van Leeuwenhoek 2006, 89 (1), 99-108. 
(51) Battaglia-Brunet, F.; Dictor, M.-C.; Garrido, F.; Crouzet, C.; Morin, D.; Dekeyser, K.; Clarens, M.; Baranger, P. An arsenic(III)-oxidizing bacterial population: selection, characterization, and performance in reactors. J. Appl. Microbiol. 2002, 93 (4), 656-667.

(52) Hao, C.; Wang, L.; Gao, Y.; Zhang, L.; Dong, H. Microbial diversity in acid mine drainage of Xiang Mountain sulfide mine, Anhui Province, China. Extremophiles 2010, 14 (5), 465-474.

(53) Hao, C.; Zhang, L.; Wang, L.; Li, S.; Dong, H. Microbial community composition in acid mine drainage lake of Xiang Mountain sulfide mine in Anhui province, China. Geomicrobiol. J. 2012, 29 (10), 886-895.

(54) Auld, R. R.; Myre, M.; Mykytczuk, N. C. S.; Leduc, L. G.; Merritt, T. J. S. Characterization of the microbial acid mine drainage microbial community using culturing and direct sequencing techniques. J. Microbiol. Methods 2013, 93 (2), $108-115$.

(55) Baker, B. J.; Hugenholtz, P.; Dawson, S. C.; Banfield, J. F. Extremely acidophilic protists from acid mine drainage host Rickettsiales-lineage endosymbionts that have intervening sequences in their 16S rRNA genes. Appl. Environ. Microbiol. 2003, 69 (9), 5512-5518.

(56) Jones, R. M.; Johnson, D. B. Iron kinetics and evolution of microbial populations in low-pH, ferrous iron-oxidizing bioreactors. 2016.

(57) Acero, P.; Ayora, C.; Torrentó, C.; Nieto, J.-M. The behavior of trace elements during schwertmannite precipitation and subsequent transformation into goethite 
and jarosite. Geochim. Cosmochim. Acta 2006, 70 (16), 4130-4139.

(58) Lawrence, R. W.; Higgs, S. A. T. W. Removing and stabilizing As in acid mine water. JOM 1999, 51 (9), 27-29. 